\title{
Tecoma stans (L.) Juss.ex Kunth (Bignoniaceae) a Prospective Mosquitocide in the Management of Zika Virus Vector Mosquito Aedes aegypti (Diptera:Culicidae)
}

\author{
M. Navaneethan ${ }^{1}$, Y. $\operatorname{Pravin}^{1}$, M. Saranya ${ }^{1}$, T. Sivakumar ${ }^{1}$, \\ R. S. Mohanraj ${ }^{1 *}$ and B. Dhanakkodi ${ }^{2}$ \\ ${ }^{1}$ Research Department of Zoology, Government Arts College, Coimbatore-641018, \\ Tamilnadu, India \\ ${ }^{2}$ Research Department of Zoology, Kongunadu Arts and Science College, \\ Coimbatore-Tamilnadu, India \\ *Corresponding author
}

Keywords

Aedes aegypti,

Tecoma stans,

Leaf Extract,

Ovicidal Activity

and Ovipositional

Deterrent Activity.

\section{Article Info}

Accepted:

24 March 2016

Available Online:

10 April 2016
A B S T R A C T

Mosquitoes are found throughout the world excluding the place which are completely frozen. Three fourth (3/4) of the existing mosquito species were native to tropical and subtropical region. Mosquitoes are likely to transmit disease to more then two fifth $(2 / 5)$ of the world population.The major dreadful disease such as Malaria, Chikungunya, Dengue, Filariasis and Japanese encephalitis were transmitted by mosquito bites. In order to reduce the awful diseases, extensive research has been done on mosquitoes for few decades. Vector control techniques face serious threats because of the emergence of resistance to synthetic insecticides. Plant are rich sources of bioactive compounds and synthesize a number of secondary metabolites to severe as defensive chemicals for control the insect pests. Plants offer an advantage over than synthetic pesticide, which used as an alternative to chemical insecticides. The present investigations were carried out to assess the ovicidal activity and ovipisitional deterrence efficiency of aqueous leaf extracts of Tecoma stans against Aedes aegypti. Hatching rate was calculated on the basis of non-hatchability of eggs. The effect of aqueous leaf extract of T.stans on oviposition of Ae. aegypti was determined under two set of conditions (Choice oviposition test, No-choice oviposition test). Oviposition Active Index (OAI) and Oviposition Deterrent Index (ODI) was calculated. The hatchability of Ae. aegypti eggs was decreased when placed in media of aqueous leaf extract. The reduction in percent hatch was inversely proportional to the concentration of aqueous leaf extract used.The aqueous leaf extract of T.stans were found to deter mosquitoes from oviposition. Oviposition Active Index and Oviposition Deterrent Index indicated a low preference of Ae. aegypti to leaf extract treated medium for egg laying. This study suggest that, the aqueous leaf extract of Tecoma stans should be considered as promising anti- mosquito agent. 


\section{Introduction}

A variety of organism like insects and arthropods affects the human health by causing various fatal disease. The insects related to epidemiology include mosquitoes, houseflies, sandflies,rat flea,tse-tse fly etc., and among these insects, mosquitoes play an important role. They are the causative agent of various fatal disease like malaria, filariasis, encephalitis, yellow fever and dengue (Gulber, 1998.).

Mosquitoes are major public health pests throughout the world. Among the 3492 species of mosquitoes recorded worldwide, more than a hundred species are capable of transmitting various diseases to humans (Reuda, 2008). Mosquito menace is particularly high in South East Asian countries (Rao et al.,2008) and in recent years global warming has lead to the spread of mosquitoes into temperate countries and higher altitude regions and the people in these regions are severely affected (Nerio $e t$ al.,2010).

Among the thirteen genera of the family Culicidae, besides Anopheles and Culex, individuals of genus Aedes are considered dangerous because they cause significant public health threat all over the world. One of the dominant species of Aedes showing wide geographic distribution and spanning both temperate and tropical climate zones is Aedes aegypti. Ae. aegypti is a mediumsized blackish mosquito easily recognized by a silvery- white Iyre- shaped pattern of scales on its scutum. The colouration of both males and females is similar. It is breeds in many types of household containers, such as water storage jars, drums, tanks and plant or flower containers (Harrington et al.,2005). Compared to any other species of Aedes, Ae.aegypti shows more dependency on human blood (Scott et al.,1993). Ae.aegypti breeds throughout the year. The eggs laid singly on the side of containers at or above the water line and also on the water surface. Hatching can take place in 2 or 3 days. These mosquitoes go through distinct stages of development: egg, larva, pupa and adult. The life cycle can be completed in about 10 days. The adult life-span of a mosquito is 50-55 days or approximately two months (Park and Park,1987).

Ae. aegypti is generally known as a vector for an arbovirus responsible for dengue fever, which is endemic to Southeast Asia, the Pacific island area, Africa and the Americas. This mosquito is also the vector of yellow fever in Central and South America and West Africa. Dengue fever has become an important public health problem as the number of reported cases continues to increase, especially with more severe forms of the disease, dengue hemorrhagic fever, and dengue shock syndrome, or with unusual manifestations such as central nervous system involvement (Pancharoen et al., 2002). About two-thirds of the world's population lives in tropical and subtropical areas infested with dengue vectors, mainly Aedes aegypti (Hahn et al.,2001).

In 1906, dengue fever seemed to be a viral illness. Dengue fever first recognized documented signs were cited in Chinese Encyclopedia in the Chin Dynasty (AD 265420). This disease was connected by means of airborne arthropods close to $\mathrm{H}_{2} \mathrm{O}$ and called as 'the water poison' (Khanani et al., 2011).The word 'dengue' is derivative from the Swahili saying Ka-dinga pepo, standing for "cramp-like seizure". The first medically documented dengue outbreaks happened in the $1780_{\text {s }}$ concurrently in Asia, Africa and North America. The first clinical case report dating from 1779 to 1780 epidemic in Philadelphia was by Gupta et al., 2012 who invented the word "break bone fever" due to indications of arthralgia and myalgia (Gupta et al., 2012). 
Dengue or 'break bone' fever had been known in our country for every long time. Dengue fever virus (DENV) belongs to RNA virus of the Flaviviridae family and it was first isolated from Japan in 1942 by Hotta (Izabela et al., 2010). The viruses of dengue are round shape particles and $50 \mathrm{~nm}$ in diameter. It holds a single strand of RNA bounded with bi layer lipid. Full-grown viruses are made up of $9 \%$ carbohydrate, $17 \%$ lipid and $6 \%$ RNA. The genomic RNA is approximately $11 \mathrm{~kb}$ in length. Dengue virus is composed of three structural protein genes(Ma et al., 2004; Modis et al., 2003). First protein gene is Enveloped (E) protein found on viral surface, second protein is membrane $(\mathrm{M})$ protein which is very important for formation of viral particles. Third protein gene is non structural (NS) proteins which has seven subtypes. These NS proteins are believed to be involved in replication of viral RNA. It is estimated that $34 \%$ of the global cases are from India (Bhatt et al., 2013) and the country is known to be endemic, with all four serotypes (DENV-1, 2, 3 \&4) circulating throughout the year in different parts (Gupta et al., 2012).

Chikungunya is an infection caused by the chikungunya virus. Chikungunya virus, also referred to as CHIKV, is a member of the alphavirus genus, and Togaviridae family. It is an RNA virus with a positive-sense single-stranded genome of about $11.6 \mathrm{~kb}$ (Weaver et al., 2012). It is a member of the Semliki Forest virus complex and is closely related to Ross River virus, O'nyong'nyong virus, and Semliki Forest virus(Powers et al., 2001). Because it is transmitted by arthropods, namely mosquitoes, it can also be referred to as an arbovirus (arthropodborne virus). The virus consists of four nonstructural proteins and three structural proteins (Weaver et al., 2015). The structural proteins are the capsid and two envelope glycoproteins: E1 and E2, which from heterodimeric spikes on the viron surface.

Zika virus (ZIKV) is a member of the virus family Flaviviridae and the genus Flavivirus, transmitted by day time-active Aedes mosquitos, such as Ae. aegypti. Its name comes from the Zika forest of Uganda, where the virus was isolated in 1947. It was later identified in humans in 1968 for the first time in Nigeria. The first major outbreak, with 185 confirmed cases, was reported in 2007 in Yap Islands. The first cases confirmed in Brazil was in May 2015 and the country is currently experiencing the largest epidemic ever recorded with 440,000 to $1,300,000$ suspected cases reported by the Brazillian health authorities. There are 3174 cases and 28 deaths from microcephaly in Brazil as of 21 October 2015 in the world. Zika virus is enveloped and icosahedral and has a nonsegmented, single-stranded, positive-sense RNA genome. It is most closely related to the Spondweni virus and is one of the two viruses in Spondweni virus clade (Kinpe et al., 2007).

Zika virus is transmitted by day-time active Ae. aegypti. Studies show that the extrinsic incubation period in mosquitos is about 10 days (Hayes, 2009). Zika virus can migrate between humans through sexual contact and it can also cross the placenta, affecting an unborn fetus. A mother already infected with Zika virus near the time of delivery can pass on virus to her newborn around the time of birth, but this is rare. These symptoms are headache, fever, skin rashes (exanthema), pink eye, conjunctivitis, muscle and joint pain, malaise. Symptoms are similar to that dengue or chikungunya.

Epidemic outbreaks of dengue fever have also been reported in India. For instance, in 1980 a total of 4,601 cases were recorded (Park and Park,1987). In October 2001, an outbreak of dengue resulting in 16 deaths 
was reported in Chennai (Tamil Nadu) India (The Hindu, 2001). In October, 2006, a total of 5,710 cases were recorded in India. Delhi had the highest $(1,637)$ patients. Tamilnadu, India had 307 patients; 103 deaths were also reported (The Hindu, 2006). In 2010, there were a total of 28, 292 cases and 110 deaths (NVBDCP, 2011). In 2012 a total of 9,000 cases and 50 deaths were reported in Madurai, Tirunelveli and Kanyakumari districts (Tamil Nadu)(The Hindu,2012). According to the Central Health Ministry of India in 2013, 75,454 people affected by this disease, in Tamilnadu alone 4,000 affected by dengue which led to 167 deaths (The Dinamani, 2013). According to Health Minister of Tamilnadu in Sivagangai district nearly 1,400 people affected by dengue fever (The Dinamalar, 2014a). In Coimbatore Corporation alone 2014, 172 people affected by dengue fever (The Dinamalar, 2014b). In 2015, nearly 2000 people affected by dengue fever in Tamilnadu (The Dinakaran, 2015).

Chikungunya, a febrile disease is caused by Chikungunya virus. There was an outbreak of this disease in Calcutta in 1963-1964 and another in Madras (Chennai) in 1965 which gave rise to 3,00,000 cases in Madras city alone (Park and Park,1987). According to Central Health Secretary of India, in 2006, 13 lakh people affected by this disease. In Tamil Nadu alone 63,000 persons were affected by this disease (The Hindu, 2006). In 2013, a total of 500 cases were reported in Thirunelvali district (Uthakulam village) Tamilnadu, India (The Dinamani, 2013). These diseases devastate Indian economy every year (Jaswanth et al., 2002).

At present, no effective vaccine is available for these diseases; therefore, the only way of reducing the incidence of this disease is mosquito control (Sarita et al., 2012). The control methods should aim at the weakest link of the life cycle of the mosquito, which is the larval stage. Larviciding is a successful way of reducing mosquito densities in their breeding places before they emerge into adults. During the immature stage, mosquitoes are relatively immobile; remaining more concentrated than they are in the adult stage (Rutledge et al., 2003).

Mosquito control has been becoming increasingly difficult because of the indiscriminate uses of synthetic chemical insecticides such as malathion, DDT, deltamethrin (Yang et al., 2005) which have an adverse impact on the environment and disturb ecological balance. Majority of the chemical pesticides are harmful to man and animals, some of which are not easily degradable and spreading toxic effects. The increased use of these insecticides may enter into the food chain. They even result in mutation of genes and these changes become prominent only after a few generations (Ghose, 1991).Thus, the Environment protection Act in 1969 has formed a number of rules and regulation to check the application of chemical control agents in nature (Bhatt and Khana, 2009). It has prompted researchers to look for alternative approaches ranging from provision of or promoting the adoption of effective and transparent mosquito management strategies that focus on public education, monitoring and surveillance, source reduction and environment friendly least-toxic larval control. These factors have resulted in an urge to look for environment friendly, costeffective, biodegradable and target specific insecticides against mosquito species.

During the last decade, various studies on natural plant products against mosquito vectors indicate them as possible alternatives to synthetic chemical insecticides (Mittal and Subbarao, 2003 and Promsiri et al., 2006). In this regard, India has a rich flora that is widely distributed throughout the country. More than 2000 
plant species have been known to produce chemical factors and metabolites of value in the pest control programmes (Ahmed et al.,1984) and among these plants, products of some 344 species have been reported to have a variety of activities against mosquitoes (Sukumar et al.,1991). Phytochemicals are advantageous due to their eco-safety, target- specificity, nondevelopment of resistance, reduced number of applications, higher acceptability and suitability for rural areas. Plants being rich source of bioactive chemicals (Rajkumar and Jebanesan, 2004) and so far there is no report of resistance to plant extracts (Sharma et al.,1992). The use of different parts of locally available plants and their various products in the control of mosquitoes have been well established globally by numerous researchers.

The phytochemicals derived from plant sources possess a complex of chemicals with unique biological activity. The phytochemicals derived from plant resources can act as larvicidal, ovicidal, oviposition deterrence, growth and reproduction inhibitors, repellents, growth regulation, fecundity suppression, male sterility (Elimam et al., 2009a,b). Some of the plant leaf extract tested for their diverse insecticidal properties on the medically important mosquitoes are:methanolic extract of Derris elliptica leaves (Prempree and Sukhapanth,1990); aqueous extract of Senna didymobotrya leaves (Ojewole et al., 2000); aqueous extract of Solanum nigrum leaves (Singh et al., 2001); acetone extract of Solanum trilobatum leaves (Rajkumar and Jebanesan, 2004); aqueous extract of Gymnema sylvestre and Eclipta prostrate leaves (Khanna and Kannabiran, 2007); methanol, benzene and acetone leaf extracts of Cassia fistula (Govindarajan, 2009);petroleum ether extract of Azadirachta indica, Ocimum gratissimum and Hyptis suaveolens leaves (Okigbo et al.,
2010); aqueous and chloroform extracts of Leucas aspera leaves (Ramanibai et al., 2011); ethanolic extract of Datura stramonium leaves (Swathi et al., 2012); aqueous extract of Spathodea campanulata leaves (Saranya et al., 2013 a, b,c);methanolic extract of Spathodea campanulata leaves (Karthika Devi et al., 2013); acetone extract of Spathodea campanulata leaves (Pravin et al., 2014); aqueous extract of Pithecellobium dulce leaves (Mahendran et al., 2015); acetone extract of Spathodea campanulata leaves (Pravin et al.,2015); methanol extract of Annona reticulata leaves (Mohankumar et al., 2016);hexane, acetone, ethanol and aqueous extracts of Agave angustifolia leaves (Kajla et al., 2016); water extract of Andrographis paniculata leaves (Wannee et al., 2016); hexane extract of Ocimum basilicum leaves (El-Akhal et al., 2016);water, chloroform, acetone and diethyl ether extracts of Nerium oleander leaves (El-Sayed and El- Bassiony, 2016); hexane, benzene, chloroform, ethyl acetate and methanol extracts of Pithecellobium dulce (Rajeswary and Govindarajan, 2016); petroleum ether,chloroform,ethanol and acetone extracts of Gmelina asiatica leaves (Augustian and Jeeva, 2016); hexane,ethyl acetate,chloroform and methanol extracts of Pedalium murex leaves (Gokulakrishnan et al., 2016);methanol extract of Ricinus cummunis and Argemone mexicana leaves (Saroj et al., 2016);methanol extract of Callistemon lanceolatus leaves (Ilango et al., 2016); ethanol extract of Hyptis suaveolens and Chenopodium ambrosoides leaves (Dawet et al.,2016);hexane, dichloromethane, ethyl acetate, acetone and methanol extracts of Spondias mombin leaves (Ajaegbu et al., 2016).

As for as our literature survey that there was no information available on the ovicidal, ovipositional detterence effects of the leaf extract of the T.stans. 
The present study was therefore carried out to evaluate mosquitocidal properties T.stans aqueous leaf extract against the vector mosquito, Ae. aegypti.

Tecoma stans (Plate-1) is a promising species in the trumpet vine family, Bignoniaceae that is native to the Americas with many synonyms and common name. Synonyms include Bignonia stans L., Gelseminum stans (L). Kuntze, Stenolobium stans(L.) Seem and Common names, yellow trumpet bush, yellow bells, yellow elder, ginger-thomas, and Esperanza.In India, it is known as Sonapatti in Tamil language, Panchalogotla in Telugu language and Korenekalar in Kannada language (Parrotta, 2001). Tecoma stans is the official flower of the United States virgin islands and the national flower of the Bahamas. It is a flowering perennial shrub or small tree, 5.7$6 \mathrm{~m}$ in height. Bark is pale brown to grey and roughens with age. Leaves are opposite, compound and imparipinnate with 2 to 5 pairs of leaflets and a larger single terminal leaflet. Leaflets are lanceolate, up to $10 \mathrm{~cm}$ long, with serrated margins, mid-green above and soft to the touch. Flowers occur in clusters at the ends of the branches and are trumpet shaped with 5 rounded lobes, $6 \mathrm{~cm}$ long, pale to bright yellow, with faint orange stripes at the throat. Fruits are narrow, slightly flattened to pointed capsules, up to $20 \mathrm{~cm}$ long, containing many winged seeds; green when young, pale brown on ripening and remain on the tree in untidy clusters for many months (Parrotta,2001). Tecoma stans leaves bark, and roots contain many biologically active chemicals, and extracts from those tissues have been used in traditional folk medicine to treat many diseases and conditions (Liogier, 1990). Leaves are used throughout Mexico and Central America for antimicrobial, antidiabetic, antispasmodic activities and urinary disorder control (Winkelman, 1986; Lozoya et al.,1987 and
Shapiro and Gong,2002). Roots are used as diuretic, vermifuge (Khare, 2007)

Chemical constituents of this botanical species are well known; numerous monoterpenic alkaloids have been identified (Hammouda et al., 1963; Arlete and Joana, 1993) and among them, tecomanine and tecostanine possess hypoglycemic effects according to observations performed in animals (Hammouda et al., 1964; Hammouda and Amer, 1966). The biosynthesis of these monoterpene alkaloids in callus tissues of $T$. stans has been studied, together with the identification of the presence of lapachol and other primary and secondary plant metabolites such as: sugars (glucose, fructose, sucrose and xylose), triterpenoids(ursolic and oleanolic acids and $\alpha$-amyrine), $\quad p$-sitosterol and phenolics (chlorogenic, caffeic, vanillic, o-cumaric and sinapicnacids). All of these compounds have already been identified in the whole plant at different concentrations (Dohnal,1976). The presence of iridoid glycosides, (Bianco et al., 1980) indolic compounds (Satya et al., 1984) in the leaves was established in T.stans (Marzouk et al., 2006).

The aim of the present study is therefore to find out: Ovicidal activity of the aqueous leaf extract T.stans of on mosquito eggs. Ovipositional preferences of adult mosquitoes to different concentrations of aqueous leaf extract of T.stans.

\section{Materials and Methods}

\section{Colonization of Aedes aegypti}

\section{Collection of Eggs}

The eggs of Aedes aegypti were collected from National Institute for Communicable Disease (NICD), Mettupalayam, Coimbatore, Tamil Nadu, India without 
exposure to any insecticide. The eggs were then brought to the laboratory and transferred to enamel trays containing water and kept for larval hatching. They were hatched and reared and have been still maintained for many generations in the laboratory. The eggs and larvae obtained from this stock were used for different experiments.

\section{Maintenance of Larvae}

The larvae were reared in plastic cups. They were daily provided with commercial fish food (Lymio et al., 1992) ad libitum. Water was changed alternate days. The breeding medium was regularly checked and dead larvae were removed at sight. The normal cultures as well as breeding cups used for any experimental purpose during the present study were kept closed with muslin cloth for preventing contamination through foreign mosquitoes.

\section{Maintenance of Pupae and Adult}

The pupae were collected from culture trays and were transferred to glass beakers containing water with help of a sucker. The pupae containing glass beaker were kept inside mosquito cage for adult emergence. The cage was made up of steel frame wrapped with mosquito netting. The cage had a provision (a hole) for handling of materials and animals placed inside. The hole was guarded with a sleeve which was useful to close suddenly after being used.

\section{Blood Feeding of Adult Ae.aegypti and Egg Laying}

The females were fed by hand every alternate day. Feeding mosquitoes on human arm for experimental purposes was suggested by Judson (1967) and Briegel (1990).
Both females and males were provided with $10 \%$ glucose solution as described by Villani et al., (1983) on cotton wicks. The cotton was always kept moist with the solution and changed every day.

An egg trap (cup) lined with filter paper containing pure water was always placed at a corner of the cage. This arrangement made the collection of eggs easier.

\section{Collection of Plant Materials}

T. stans leaves (Plate 2) were collected from Periyanaickenpalayam village, Coimbatore District, Tamilnadu, India. The identification of the plant was authentified at BSI (Botanical Survey of India), Coimbatore (Reference number BSI/SRC/5/23/2015/Tech/41).

\section{Preparation of Plant Extract}

The fresh leaves of $T$. stans were collected in the Periyanaickenpalayam village, Coimbatore District, Tamilnadu, India. Then the leaves brought to the laboratory. The plant leaves were observed carefully for any kind of diseases or infection and if found any, those parts were separated and not used for the experiment. The selected leaves washed with distilled water in order to clean dust or any particle stuck to them. Then the leaves kept for drying under shade at room temperature $\left(27 \pm 2^{\circ} \mathrm{C}\right)$ for about 2 weeks till they dried completely. The leaves were finely powdered using electric blender. Powdered plant material (100g) was soaked in double distilled water (1000 ml) in airtight wide mouth bottle and kept for 4 days with periodic shaking. After that, the cold extract was filtered using Whatman No.1filter paper and kept in petri dishes for drying at room temperature (Kongkathip,1994). Dried extract was used for the preparation of stock solution. 
Preparation of Stock Solution and Different Concentrations of Leaf Extract

$1 \mathrm{~g}$ of the concentrated extract of T.stans leaves was dissolved in $100 \mathrm{ml}$ tap water and kept as stock solution. This stock solution was used to prepare the desired concentrations of the extract for exposure of the mosquito larvae.

\section{Ovicidal Assay}

Freshly laid eggs obtained from the general stock of mosquitoes were tested for their hatching ability in relation to the different concentrations of aqueous leaf extract of T.stans. Hatching rate was calculated on the basis of non-hatchability of eggs according to Sahgal and Pillai (1993).

Five replications were conducted at each concentration of test compound.

The data were statistically examined using Student's $t$-test.

\section{Oviposition Bioassay}

The effect of aqueous leaf extract of T.stans on oviposition of Ae. aegypti was determined under two set of conditions (Choice oviposition test, No-choice oviposition test) as suggested by Beehler and Mulla (1993), Chen et al., (1996) and Dhanakkodi et al., (1999).

Oviposition Active Index (OAI) was calculated as detailed by Vasuki (1991) using the formula,

$$
\mathrm{OAI}=\frac{\mathrm{Nt}-\mathrm{NS}}{\mathrm{Nt}+\mathrm{NS}}
$$

Where

$\mathrm{Nt}$ is the total number of eggs in test solutions and

NS is the total number of eggs in control
This would indicate whether the effect of the compound on oviposition is positive or negative.

Further, the percentage of oviposition deterrence (oviposition deterrent index of Lundgren, 1975) was determined according to the formula given by Dimetry et al., (1995).

Oviposition Deterrent Index $(\mathrm{ODI})=\frac{\mathrm{B}-\mathrm{A}}{\mathrm{A}+\mathrm{B}} \times 100$

Where

A - is the number of eggs laid on treated

$\mathrm{B}-$ is the number of eggs laid on control.

The data were statistically examined using Student's $t$ - test.

\section{Results and Discussion}

Effect of Aqueous Leaf Extract of T.stans on Hatching of Ae. aegypti Eggs

Freshly laid eggs obtained from the general stock of mosquitoes were tested for their hatching ability in relation to the different concentrations of aqueous leaf extract of T.stans. Percent hatch of eggs placed in control medium was $90 \%$ where as in 0.1 , $0.5,0.10,0.15$ concentrations it was 75,55 , 45 and 10. $0.20 \%$ dose completely arrested hatching eggs (Table- 1). The decrease in hatchability was found to be dose dependent.

\section{Effect of Aqueous Leaf Extract of T.stans on Oviposition of Ae.aegypti}

\section{Choice Oviposition Test}

Mosquitoes showed more preference towards control ovitrap for oviposition, though; media of different concentrations of aqueous leaf extract of T.stans were 
available along with control (Choice oviposition test). The total number of eggs laid in ovitraps containing any concentration of the aqueous leaf extract of T.stans was always less then that in the control. Among the total number of eggs laid, $49.58 \%$ was present in control medium when placed along with ovitraps with $0.1,0.5,0.10$ and $0.15 \%$ aqueous leaf extract of T.stans in which appeared 30.57, 13.22, 5.785 and $0.826 \%$ of eggs respectively. This was also indicated by ODI values $(23.17,57.89$ and 79.10 and 96.72). Rate of oviposition in ovitraps with any concentration of test compounds was significantly $(\mathrm{P}<0.001)$ less than in control (Table-2).

\section{No - choice Oviposition Test}

The ovipositional deterrence of aqueous leaf extract of T.stans against Ae. aegypti was also confirmed by the results of "no - choice test' where ovitrap with any one of the concentrations accompanied the control. Percent oviposition in $0.1,0.5,0.10$ and $0.15 \%$ of aqueous leaf extract of T.stans was $33.33,23.68,8.510$, and 2.803 which were significantly $(\mathrm{P}<0.001)$ less compared to their control counterparts 66.66, 76.31, 91.48 and $97.19 \%$, respectively. The data of no - choice oviposition test clearly exhibited interference of aqueous leaf extract of T.stans on the oviposition preference of mosquitoes (Table-3).

The extensive use of synthetic chemical insecticides has resulted in environmental degradation, hazards and resistance to these insecticides in major vector species. This has necessitated the formulation of a more potent and environment-friendly insecticide. Since last few years, the researchers have focused their interest towards the control of mosquito larvae with the use of plant extracts. Plants have been known to produce various chemicals, many of which have reported to possess medicinal, insecticidal and pesticidal properties. More than 2000 plant species have been known to produce chemical factors and metabolites of value in pest control programmes. A number of plant extracts has been reported to possess larvicidal, adulticidal or repellent activities against different species of mosquitoes (Ghosh et al., 2012).

The crude methanol and benzene leaf extract of Cardiospermum halicacabum exerted $100 \%$ reduction of egg hatching at $300 \mathrm{ppm}$ against Cx.quinquefasciatus and in $A e$. aegypti $100 \%$ reduction of egg hatching at 400 ppm (Govindarajan, 2011b); an acetone extract of Solanum trilobatum leaves was evaluated for its ovicidal activity on the Cx.quinquefasciatus and $C x$. tritaeniorhynchus, by exposing eggs ranging concentrations of $50-200 \mathrm{ppm}$ of the extract and a $100 \mathrm{ppm}$ of the extract killed all the eggs from both the species (Rajkumar and Jebanesan, 2004); ovicidal activity with ethyl acetate, aqueous solution, ethanol leaf extracts of Nerium oleander against An. stephensi at 100,150,200,250, and $300 \mathrm{ppm}$ were calculated. With each extract at a concentration of $100 \mathrm{ppm}$, the percentage of hatchability was very high and nil hatchability was recorded when the concentration of extract was increased to $300 \mathrm{ppm}$ in the case of aqueous and ethanol extracts (Roni et al.,2013); percent hatch of eggs placed in control medium was $80 \%$ where as in $0.1 \%, 0.2 \%, 0.4 \%$ and $0.6 \%$ concentrations of aqueous leaf extract of Spathodea campanulata against Ae.aegypti was 65, 46, 40 and 20\%. $0.8 \%$ dose completely arrested hatching eggs (Saranya et al., 2013b); it has been noticed that higher concentrations of Pongamia pinnata leaves extracts possesses strong ovicidal activity $100 \%$ at $400 \mathrm{ppm}$ concentration against Ae.aegypti, An.stephensi and Cx.quinquefasciatus. In the same way, methanol extracts showed maximum ovicidal activity at 240,320, and $400 \mathrm{ppm}$ 
followed by hexane, dichloromethane and ethyl acetate against vector mosquitoes (Anitha et al., 2014); maximum percentage of Ae.aegypti, An. stephensi and Cx.quinquefasciatus eggs was killed when they were exposed to $500 \mathrm{ppm}$ concentration of Clausena excavate leaves of the methanol extract (Thangarasu et al., 2014); the diethyl extract of Coleus aromaticus leaves exerted $100 \%$ ovicidal activity against Ae. aegypti at 200ppm (Baranitharan and Dhanasekaran, 2014); at 100ppm concentration of Dodonaea viscose and Lantana camara leaves had the most severe effect on Ae. aegypti egg hatching rate which were reduced by about $35 \%$ and $33.5 \%$ compared with $26 \%$ for Ruta chalepensis.At their highest concentrations (500 ppm), the plant extract reduced egg hatchability percentages by about $90 \%, 87 \%$ and $69 \%$ for Dodonaea viscose and Lantana camara and Ruta chalepensis respectively (Madkour et al., 2014) ; the higher concentrations of Polygala arvensis leaf methanol extract possesses strong ovicidal activity at 200 ppm concentration against Ae.aegypti, An.stephensi and Cx.quinquefasciatus, no egg hatchability was recorded (Deepa et al., 2014); one hundred per cent egg mortality was obtained in ethyl acetate extract of Ageratum houstonianum leaves at $20.0 \mathrm{mg} / \mathrm{L}$ against $A$ e. aegypti (Samuel et al., 2015); the methanol extract of Ageratum conyzoides leaves exerted $100 \%$ egg mortality at 250 ppm against An. stephensi (Janakan and Ramakrishnan, 2014); the acetone leaf extract of Argemone mexicana was found to exhibit the highest ovicidal potential against Ae.aegypti with a significantly reduced egg hatch of $27.32 \%$ when exposed to $400 \mathrm{ppm}$ extract as compared to control treatment; this extract causing the lowest percent hatch of $18.35 \%$ at 1000 ppm (Radhika and Sarita, 2015); both plant extract (acetone) exhibited excellent oviciding effect as $92.33 \%$ of eggs failed to be hatched when treated with 705.0 $\mathrm{mg} / \mathrm{L}$ of Melanochyle fasciculiflora and $86.67 \%$ with $562.5 \mathrm{mg} / \mathrm{L}$ of Gluta renghas leaves (Zuharah et al., 2015).

In the case of ovicidal activity, exposure of freshly laid eggs was more effective than that of the older eggs (Miura et al.,1976).

The aqueous extract treated eggs exhibited an allayed hatchability and this may be due to the action of phytochemicals present in the extract. The extract may inhibit the hatchability of the eggs by interfering with their chorion (Rajkumar et al.,2011). Eggs and egg shells treated with plant extracts become damaged probably due to endosmosis. After the initial phase of swelling, eggs become desiccated, followed by shrinkage and death of larvae trapped within (Arivoli and Samuel 2011d). The treated eggs contained developed embryos the eclosion of the egg was incomplete (Miura et al.,1976).

The findings of the present investigation were comparable with other ovicidal studies and revealed that the aqueous T.stans leaf extract possesses ovicidal activity against the eggs of Ae. aegypti.

One of the approaches to control the expanding mosquito population is to deter oviposition of female adults. In the absence of a suitable site for oviposition, the female avoid oviposition leading to its regression. Such an event can strongly influence vector population distribution and dynamics as well as provide additional understanding into the factors affecting population regulation (Kweka et al., 2010). It has also been reported that reduce exposure to predators and competitors or increase access to food. In fact, in the presence of oviposition deterrents, female mosquitoes move towards and land upon a site, assess site quality, but lay few or no eggs before flying away (Xue et al., 2003). 
Table.1 Altration in the Hatchability of Aedes aegypti Eggs Exposed to Differen Concentrations of Aqueous Leaf Extract of T.stans and Control

\begin{tabular}{|c|c|c|c|c|c|c|}
\hline & & \multicolumn{4}{|c|}{ Concentrations (\%) } \\
\cline { 3 - 6 } Parameters & Control & 0.1 & 0.5 & 0.10 & 0.15 & 0.20 \\
\hline Number of eggs introduced & 20 & 20 & 20 & 20 & 20 & 20 \\
Mean number of eggs hatched \# & 18.66 & 15.33 & 11.66 & 9.00 & 2.66 \\
S.D & \pm 0.010 & \pm 0.102 & \pm 0.020 & \pm 0.012 & \pm 0.210 & \pm 0.011 \\
Percent hatchability & 90 & $75^{*}$ & $55^{*}$ & $45^{*}$ & $10^{*}$ & $0^{*}$ \\
Percent reduction over control & & 16.66 & 38.88 & 50.00 & 88.88 & 100 \\
& & & & & & \\
\end{tabular}

\#, Mean ( \pm SD) of 5 replicates.

*, Significantly different from control, $\mathrm{P}<0.001$

Table.2 Changes in the Indices of Oviposition Deterrence at Different Concentrations of Aqueous Leaf Extract of T.stans against Aedes aegypti under Choice Oviposition Test

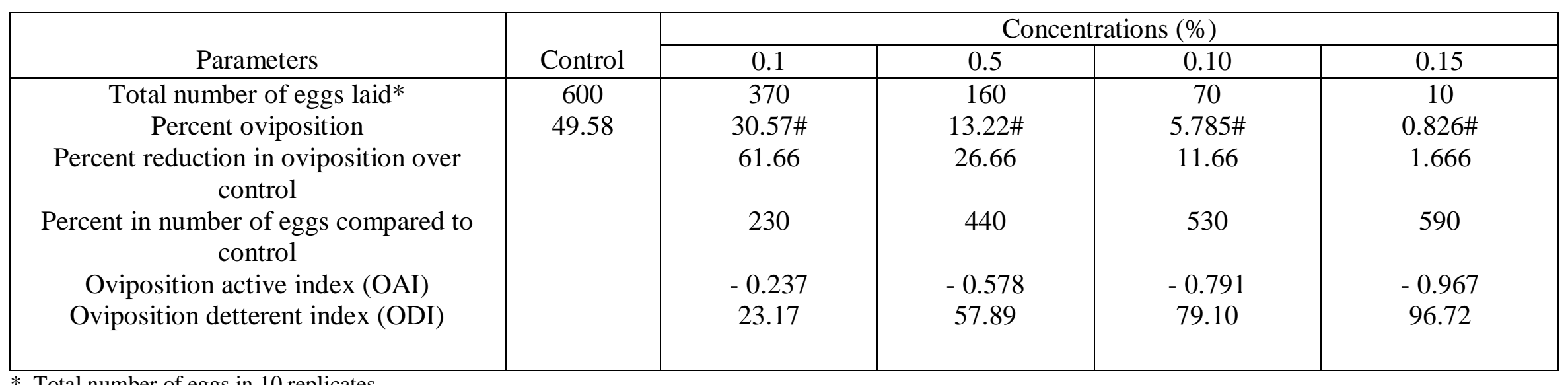

*, Total number of eggs in 10 replicates.

\#, Significantly different from control, $\mathrm{P}<0.001$ 
Table.3 Changes in the Indices of Oviposition Deterrence of Different Concentrations of Aqueous Leaf Extract of T.stans against Aedes aegypti under No-choice Oviposition Test

\begin{tabular}{|c|c|c|c|c|c|c|c|c|}
\hline \multirow[b]{2}{*}{ Parameters } & \multicolumn{8}{|c|}{ Concentrations (\%) } \\
\hline & $\mathrm{C}$ & 0.1 & $\mathrm{C}$ & 0.5 & $\mathrm{C}$ & 0.10 & $\mathrm{C}$ & 0.15 \\
\hline Total number of eggs laid* & 300 & 150 & 290 & 90 & 430 & 40 & 520 & 15 \\
\hline Percent oviposition & 66.66 & 33.33\# & 76.31 & 23.68\# & 91.48 & $8.510 \#$ & 97.19 & 2.803\# \\
\hline Percent reduction over control & & 50 & & 31.03 & & 9.302 & & 2.884 \\
\hline $\begin{array}{l}\text { Reduction in number of eggs compared } \\
\text { to control }\end{array}$ & & 150 & & 200 & & 390 & & 505 \\
\hline Oviposition active index (OAI) & & -0.333 & & -0.526 & & -0.829 & & -0.943 \\
\hline Oviposition deterrent index (ODI) & & 33.33 & & 52.63 & & 82.97 & & 94.39 \\
\hline
\end{tabular}

*, Total number of eggs in 3 replicates.

\#, Significantly different form control, $\mathrm{P}<0.001$ 
Plate.1 Shows the Tree Tecoma stans from which Leaves Collected for this Study

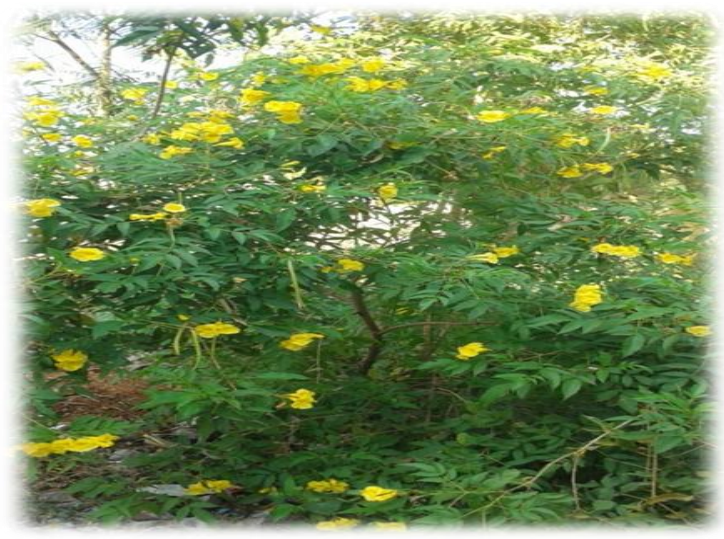

Plate.2 Shows the Leaves of Tecoma Stans with Which the Extract was Prepared

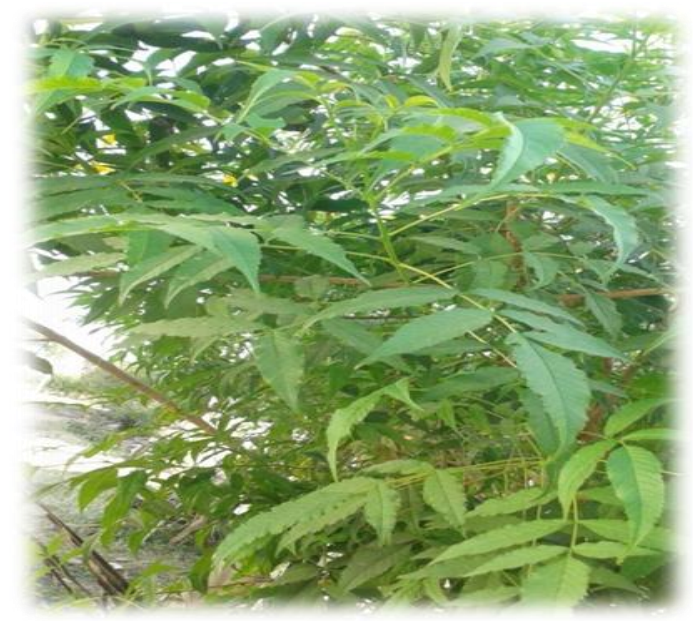

It has been reported that the oviposition activity index represents the relative preference of a substrate by egg-laying females (Waliwitiya et al., 2009). Positive index values indicate more oviposition in the test cups than in control cups, whereas more eggs in control cups as compared to the test cups results in negative index values. The negative OAI values, thus, indicate the preference of distilled water as the medium for egg deposition over the treated medium which proved repulsive or unsuitable.

Oviposition active index for both ethanolic leaf extract of Ocimum kilimandscharicum
(OK) and Ocimum suave (OS) experiments egg lay in a negative side ranged from $-1 \%$ to $-0.19 \%$. It was showed that OS and OK deter ovipoistion in An. gambiae (Kweka et al.,. 2010); ethanolic extract of Pongamia pinnata, Coleus forskohlii and Datura stramonium leaves reduced egg laying by $97.62 \%$, $77.3 \%, 100 \%$ against Ae. aegypti and $59.10 \%, \quad 39.22 \%, \quad 82 \%$ against Cx.quinquefasciatus at higher concentration (0.1\%) (Swathi et al.,2010); the ethanolic leaf extract of Solanum trilobatum was tested under laboratory conditions for oviposition deterrent activities against the adult An.stephensi 
and the concentrations of $0.01,0.025$, $0.05,0.075$ and $0.1 \%$ reduced egg laying by females from 18 to $99 \%$ (Rajkumar and Jebanesan, 2005 a); the oviposition active index (OAI) value of acetone, ethyl acetate, and methanol extracts of Aegle marmelos, Andrographis lineate and Cocculus hirsutus leaf at 500 ppm against An. subpictus were $-0.86,-0.87,-0.90$, 0.78 and $-0.87,-0.86,-0.91,-0.94$ and 0.86 respectively and the OAI values revealed that the solvent plant extracts have deterrent effect, and they caused a remarkable negative response resulting an oviposition of very few eggs (Elango et $a l ., 2009)$; in oviposition deterrent activity, the highest concentration of $(0.1 \%)$ ethanolic leaf extract of Vitex negundo produce $94.2 \%$ in Ae.aegypti, $96.4 \%$ in An.stephensi and $99.8 \%$ in $C x$. quinquefasciatu (Vijaya kumar et al.,2011a); the highest concentration of $(0.1 \%)$ acetone, chloroform, hexane, petroleum ether and ethanol extracts of Annona squamosa leaves produce oviposition deterrent activity $99.6 \%$ against An. stephensi, $92.4 \%$ against $C x$. quinquefasciatus and $92.4 \%$ against $A e$. aegypti respectively (Vijaya kumar et al.,2011b); acetone extract of Prosopis juliflora leaf found to be strong oviposition deterrent which inhibited egg laying (OAI-0.466) at $100 \mathrm{ppm}$ (Yadav et al., 2014); the maximum oviposition deterrent activity was recorded from the highest concentration of methanol, hexane,dichloromethane and ethyl acetate extracts $400 \mathrm{ppm}$ and the least oviposition deterrent activity was recorded from the 80 ppm concentration of Pongamia pinnata leaves extracts against mosquitoes (Anitha et al., 2014); the maximum oviposition deterrent potential of the petroleum ether extract of Argemone mexicana leaves against Ae.ageypti with $31 \%$ effective deterrence at $200 \mathrm{ppm}$ which rose by $66 \%$ at 400 ppm (Radhika and Sarita,2015).

The oviposition is one of the most important events in the life cycle of mosquitoes (Xue et al.,2001). If oviposition is prevented the mosquito life cycle is disrupted and population growth is reduced. The present oviposition study shows that the aqueous leaf extract of T.stans act as oviposition deterrent, this indicates that Ae. aegypti mosquitoes were acutely sensitive to phytochemical stimuli and respond to the odour of the leaf extract. The strong odour produced by higher concentration of aqueous leaf extract produce maximum effective repellence against oviposition. The mosquitoes are known to select or reject their specific oviposition sites by sensing chemical signals that are detected by sensory receptors on the antenna (Davis and Bowen, 1994)

T.stans aqueous leaf extract used for the first time in this study to assess their ovicidal and oviposition deterrent activities against the dengue vector $A e$. aegypti and the extract exhibited remarkable results.

To avoid the detrimental effects caused by the chemicals for the control of dengue vector, natural and nontoxic bioactive compounds of plant origin can be used as an alternate control measure (Das et al., 2007). This study finally proposed new alternative potential biopesticides from local flora, which is easily available with low technology and can easily be integrated into the ongoing mosquito management rather than using conventional chemical control, which is more expensive than using the biological control comprising of plant extracts and is more effective and target specific (Jaenson 
et al., 2006). Our investigations have indicated the potential of T.stans leaves as the possible and effective control agent against Ae. aegypti. The studies recommend that this plant could form safe and eco-friendly alternative to eco-enemy synthetic pesticides. Further studies regarding enhancing effectiveness, constancy, noxious effects and impacts on non-target population and the environment, along with field trials are required to recommend T.stans as an antimosquito agent.

\section{References}

Ahmed, S., Graivge, M., Hylin, J.M., Mitchell, M.C., Listinger J.A.1984.Some promising plant species for use as pest control agents under traditional farming system. In: Schmutterer. and Ascher K.R.S., (eds) Proc. $2^{\text {nd }}$ International neem conference, Rauischolzhausen, Germany; pp. 565-580 GTZ, Eschborn, Germany.

Ajaebu, E.E., Danga, S.P., Chijoke, I.U., Okoye, F.B.C.2016. Mosquito adulticidal activity of the leaf extracts of Spondias mombin L. against Aedes aegypti L. and isolation of active priniciples.J.Vector Born Dis., 53 : 17-22.

Anitha,S.S., Thiraviaraj, S., Dhanasekaran, S.2014.Mosquitocidal activities of Pongamia pinnata Linn against Aedes aegypti (Linn.), Anopheles stephensi Liston and Culex quinquefasciatus (Say) (Diptera: Culicidae). Int. J. Curr. Inno. Res., 1: 51-57.

Arivoli, S., Samuel, T. 2011d. Studies on mosquitocidal activity of Murraya koenigii (L.) Spreng (Rutaceae) leaf extract against Aedes aegypti,Anopheles stephensi and Culex quinquefasciatus (Diptera : Culicidae). Asian J. Exp. Biol. Sci., 1 : 721 - 730.

Arlete, P.L., Joana, D.F. 1993. Monoterpene alkaloids from Tecoma stans.Phyto. Che., 34: 876-878.

Augustian, R.F., Jeeva, S.2016. Larvicidal activity of Gmelina asiatica L. leaf extracts against Aedes aegypti and Culex quinquefasciatus. A nn. Biolo. Res., 7:12-20.

Baranitharan, M,. Dhanasekaran, S. 2014. Mosquitocidal efficacies of medicinal plant of Coleus aromaticus Benth (Lamiaceae) leaf extracts against chikungunya vector, Aedes aegypti (Linn.) (Diptera: Culicidae). Int. J. Curr.Res. Chem. Pharma. Sci., 1: 61-67.

Beehler, J.W., Mulla, M.S.1993. Effect of the insect growth regulator methoprene on the oviposition behaviour of Aedes aegypti and Culex quinquefasciatus. J. Am. Mosq. Control Assoc., 9: 13 -16.

Bhatt, R.P., Khana, S.N. 2009. Environmental impact assessment system in Nepal - an overview of policy, legal instruments and process. Kathmandu Univ. J. Sci. Engi. Tech.,5: 160-170.

Bhatt, S., Gething, P.W., Brady, O.J., Messina, J.P., Farlow, A.W., Moyes, C.L., Drake, J.M., Brownstein, J.S., Hoen, A.G., Sankoh, O., Myers, M.F., George, D.B., Jaenisch, T., Wint, G.R., Simmons, C.P., Scott, T.W., Farrar, J.J., Hay, S.I.2013. The global distribution and burden of dengue. Nature., 25: 504-507.

Bianco, A., Guiso, M., Marini Bettolo, R., Oguakwa J. 1980. New iridoids from Tecoma stans and Lamium amplexicaule. Planta. Medica., 39: 268.

Briegel, A.1990. Metabolic relationship between female body size, reserves, and fecundity of Aedes aegypti. J.Insect physiol.,36: 165 - 172.

Chen, C.C., Dong, Y.J., Cheng, L.L., Hou, R.F.1996. Deterrent effect of neem seed kernel extract on oviposition of the oriental fruit fly (Diptera :Tehritidae) in guava. J. Econ. Entomol.,89 : $462-$ 466.

Das, N.G., Goswami, D., Rabha, B.2007. Preliminary evaluation of mosquito larvicidal efficacy of plant extracts. $J$. Vec. borne. Dis.,44: 145-8.

Davis, E.E.,Bowen, F.M.1994. Sensory physiological basis for attraction in 
mosquitoes. J. Am. Mosq. Control Assoc., 10 : 316-325.

Dawet, A., Ikani, G., Yakubu., D.P. 2016. Larvicidal effects of Hyptis suaveolens and Chenopodium ambrosoides on Anopheles mosquito larvae. Int. J. Sci. Engee. Res., 1: 455-470.

Deepa, M., Palanisamy, K., Krishnappa, K., Elumalai, K. 2014.Mosquitocidal activity of Polygala arvensis Willd against Aedes aegypti (Linn.), Anopheles stephensi (Liston.) and Culex

quinquefasciatus (Say.) (Diptera: Culicidae). Int. J. Mosq. Res., 1: 30-34.

Dhanakkodi, B., Saraswathi, S., Thangavel, K., Mohanraj, R.S.1999.Influence of neem based formulations on ovipositional preference of Aedes aegypti. In : Biopesticides in insect pest management. S. Ignacimuthu and Aloksen. (Eds). Phoenix Publishing House Pvt. Ltd., New Delhi pp. 6870.

Dimetry, N.Z., Barakat, A.A., Abdulla, E.F., EI - Metwally, H.E,. Abd EI -Salam, A.M.E. 1995. Evaluation of two neem seed kernel extracts against Liriomyza trifolii Burg. Anz Schadlingskde $P$. flanzenschutz Umweltschut, 68 : 39-41.

Dohnal, B. 1976. Investigations on some metabolites of Tecoma stans Juss. Callus tissue. Acta Soc. Bot. Polo.,45: 369-379.

El-Akhal, F., Guemmouth, R., Zerrouq, F., Ez Zoubi, Y., EI Ouali Lalami,A.2016. Struggle against vector-borne disease: phytochemical screening and larvicidal activity of hydro-ethanolic extract of Ocimum basilicum and north east of Morocco against the larvae of malaria vector mosquito Anopheles labranchiae (Diptera: Culicidae). Int.J.Phar. Phyto. Chem. Res., 8: 284-288.

Elango,G., Bagavan, A., Kamaraj, C., Abdul Zahir, A., Abdul Rahuman A.2009. Oviposition deterrent, ovicidal and repellent activities of indigenous plant extracts against Anopheles subpictus Grassi (Diptera:Culicidae). Parasitol. Res., 105: 1567-1576.

Elimam, A.M., Elmalik, K.H., Ali, F.S.2009a.
Efficacy of leaves extract of Calotropis procera Ait.(Asclepiadaceae) in controlling Anopheles arabiensis and Culex quinquefasciatus mosquitoes. Saudi. J. Biol. Sci.,16: 95-100.

Elimam, A.M., Elmalik, K.H., Ali, F.S.2009b. Larvicidal, adult emergence inhibition and oviposition deterrent effects of foliage extract from Ricinus communis L. against Anopheles arabiensis and Culex quinquefasciatus in Sudan.Trop. Biomed., 26:13-139.

El-Sayed,S.H., El-Bassiony, G.M. 2016. Larvicidal, biological and genotoxic effects, and temperature toxicity relationship of some leaf extracts of Nerium oleander (Apocynaceae) on Culex pipiens (Diptera: Culicidae). J. Arthropod-Borne Dis., 10: 1-11.

Ghose,G.K.1991. Biopesticide and integrated pest management. A.P.H. Publishing Corporation, New Delhi, 145-146.

Ghosh, A., Chowdhury, N.,Chandra, G. 2012. Plant extracts as potential mosquito larvicides. Indian J. Med. Res., 135: 581598.

Gokulakrishnan, J., Baranitharan, M., Dhanasekaran, S., Deepa, J., Selvakumar B., Thushimenan,

S.2016.Laboratory evaluation of Pedalium murex L. extracts on the south east India disease vector mosquitoes (Diptera:Culicidae). Int. J. Zool. Appl. Biosci., 1:7-14.

Govindarajan, M.,2009. Bioefficacy of Cassia fistula Linn. (Leguminasae) leaf extract against Chikungunya vector Aedes aegypti (Diptera : Culicidae). Eur.Rev. Med. Pharmacol. Sci., 13:99-103.

Govindarajan, M. 2011b. Mosquito larvicidal and ovicidal activity of Cardiospermum halicacabum Linn. (Family : Sapindaceae) leaf extract against Culex quinquefasciatus (Say) and Aedes aegypti. (Linn.) (Diptera : Culicidae). Eur. Rev. Med. Pharmacol. Sci., 15 : 787 794.

Gubler, D.J.1998. Aedes aegypti and Aedes aegypti-borne disease-control in the 1990s top down or bottom up. Am. J. 
Trop. Med. Hyg., 40: 571-578.

Gupta, N., Srivastava, S., Jain, A., Chaturvedi, U.C. 2012. Dengue in India. Int.J. Med. Res., $\quad$ 136: 373-390.

Hahn, C.S., French, O.G., Foley, P., Martin, E.N., Taylor R.P. 2001. Biospecific monoclonal antibodies of dengue virus to erythrocytes in a monkey model of positive viremia. J. Immunol., 66: 10571065.

Hammouda, Y., Amer, M. 1966. Antidiabetic effect of tecomine and tecostanine. $J$. Pharm. Sci., 55: 1452-1454.

Hammouda,Y., Plat, M., Le Men, J. 1963. Structure de la tecostanine: alcaloide du Tecoma stans Juss. Anna. Pharma.Franc.,21: 699-702.

Hammouda,Y., Rashid, A., Amer, M. 1964. Hypoglycemic properties of tecomine and tecostanine. J. Pharm. \& Pharmco., 16: 833-834.

Harrington, L.C., Scott, T.W., Lerdthusnee, K., Coleman, R.C., Coctero, A., Clark G.G., Jones J. J.,Kitthawee, S., Kittqyapong, P., Sithiprasasna, R., Edman,J.D. 2005.Dispersal of the dengue vector Aedes aegypti within and between rural communities part 1. Am.J. Trop. Med Hyg., 72: 209-220.

Hayes,E.B. 2009. Zika Virus Outside Africa. Emer. Infet. Dis., 15: 1347-1350.

Ilango, S., Athirstalaxmi, D., Malarvizhi., M. 2016. Effect of phytochemicals on fecundity and hatchability of Culex quinquefasciatus and Anophels stephensi. Int. Res. J. Biological. Sci. 3:31-39.

Izabela, A., Zybert, R., Wilschut, J.2010. Dengue virus life cycle: viral and host factors modulating infectivity. Cell. Mole. Life Sci., 67: 2773-2786.

Jaenson, T.G., Palsson, K., Borg-Karlson, A.K. 2006. Evaluation of extracts and oils of mosquito

(Diptera: Culicidae) repellent plants from Sweden and guonea-bissau. J.Med. Entomol.,43:113-9.

Janakan, R., Ramakrishnan, N.2014. Mosquitocidal activity of Barleria prionitis Linn (Acanthaceae) and
Ageratum conyzoides Linn (Asteraceae) against malarial vector mosquito Anopheles stephensi Liston (Diptera: Culicidae). Int. J. Curr. Inno. Res., 1: 4550.

Jaswanth, A., Ramanathan, P., Rukmani, K. 2002. Evaluation of mosquitocidal activity of Anonna squamosa leaves against filarial vector of Culex quinquefasciatus (Say). Indian J. Exp. Biol., 40:363-365.

Judson, C.L.1967. Alternation of feeding behaviour and fertility in Aedes aegypti by the chemosterilant apholate. Entomol. Exp. Appl. 10: 387394.

Kajla, M., Bhattacharya, K., Gupta, K., Banerjee, U., Kakani, P., Gupta, L., Kumar S.2016. Identification of the temperature induced larvicidal efficacyof Agave angustifolia against Aedes, Culex and Anopheles larvae. Fornt. Pub. Heal., 12:1-11.

Karthika Devi, K., Mohanraj, R.S., Dhanakkodi, B.2013. Mosquitocidal activites of Spathodea campanulata methanolic leaf extract against the dengue vector Aedes aegypti. Asian J. Plant Sci. Res., 3: 138 - 149.

Khanani, M.R., Arif, A., Shaikh, R. 2011. Dengue in Pakistan: journey from a disease free to a hyper endemic nation. J. Dow. Univ. Health. Sci., 5: 8184.

Khanna, V.G., Kannabiran, K. 2007. Larvicidal effect of Hemidesmus indicus, Gymnema sylvestre and Eclipta prostrate against Culex quinquefasciatus mosquito larvae. African. J. Biotech.,6: 307311.

Khare, C.P. 2007. Indian medicinal plants: An illustrated dictionary, Springer India, New Delhi., 648-649.

Knipe, A., David M., Howley, C., Peter, M. 2007. Fields virology. Lippincott Williams \& Wilkins. 1156-1199.

Kongkathip, N. 1994. Chemistry and extraction method of neem- Bankok: $3{ }^{\text {rd }}$ Workshop in the using neem leaf extracts for control and eradicate insects 
Kweka,E.J., Lyatuu, E.E., Mboya, M.A., Beda, J.M., Mahande, A.M. 2010. Oviposition deterrence induced by Ocimum kilimandscharicum and Ocimum suave extracts to gravid Anopheles gambiae S.S (Diptera: Culicidae) in laboratory. J. Glob. Infect. Dis., 2: 242245.

Liogier, H.A. 1990. Plantas medicinales de Puerto Rico y del Caribe. Iberoamericana de Ediciones, Inc., San Juan PR. 566.

Lozoya, X., Aguilar, A.,Camacho, J.R. 1987. Encuestasobre el uso actual de las plantas en la medicina tradicional Mexicana. Revista. Medica. Del. Institute. Mexicano. Del. $\quad$ Seguro. Social., 25: 283-291.

Lymio, E.O., Takken, W., Koella, J.C.1992. Effect of rearing temperature and larval density on larval survival, age at pupation and adult size of Anopheles

gambiae. Entomol. Exp. Appl., 63: 265-271.

Ma, L., Jones, C.T., Groesch, T.D. 2004. Solution structure of dengue virus capsid protein reveals another fold. Proc. Natl. Acad. Sci. USA., 101: 3414-3419.

Madkour, M.H., Zaitoun, A.A., Singer, F.A. 2014. Innovative biocontrolling method of dengue fever vector, Aedes aegypti (Diptera: Culicidae). J. Agri. Sci., 6: 208213.

Mahendran, S., Pravin, Y., Saranya, M., Sivakumar, T., Mohanraj, R.S., Dhanakkodi,B. 2015. Ovipositional deterrence, ovicidal and developmental effects of Pithecellobium dulce

(Roxb.) Benth. (Fabaceae) aqueous leaf extract against dengue vector mosquito Aedes aegypti (Diptera: Culicidae). Int. J. Curr. Res. Biosci. Plant Biol., 2: 79-91.

Marzouk, M., Gamal-Eldeen A., Mohamed, M., El Sayed,M. 2006. Antiproliferative and antioxidant constituents from Tecoma stans, $Z$. Naturforsch.,61: 783-791.

Mittal, P.K., Subbarao, S.K.2003. Prospects of using herbal products in the control of mosquito vectors. I.C.M.R. Bul.,33:112.
Miura, T., Schaefer, C.H., Takahashi, R.M., Mulligan, F.S. 1976. Effects of the insect growth inhibitor, dimilin on hatching of mosquito eggs. J. Econ. Entomol.,69: 655-658.

Modis, Y., Ogata, S., Clements, D. 2003. A ligand-binding pocket in the dengue virus envelope glycoprotein. Proc. Natl. Acad. Sci. USA., 100: 6986- 6991.

Mohankumar, T.K., Kumuda, S.S., Vijayan, V.A. 2016. Screening of methanolic plant extracts against larvae of Aedes aegypti and Anopheles stephensi in Mysore. J. Arthropod.-Borne Dis., 10: 305-316.

National Vector Borne Disease Control Programme (NVBDCP). 2011. Dengue cases and Deaths in the country since 2007. Available at : http:// nvbdcp.gov.in/ den. cd. html.

Nerio, L.S., Olivero-Verbel, J., Stashenko, E.2010. Repellent activity of essential oils. A review.Bioresource Technol., 101: 372-378.

Ojewole, J.A.O., Rahim, S., Shode, F.O. 2000. Mosquito larvicidal properties of aqueous extract of Senna didymobotrya. Nig. J. Nat. Prod. Med., 4:46-47.

Okigbo, R.N., Okeke, J.J., Madu, N.C.2010. Larvicidal effects of Azadirachta indica, Ocimum gratissimum and Hyptis suaveolens against mosquito larvae. J. Agri. Tech.,6: 703-719.

Pancharoen, C., Kulwichit, W., Tantawichien, T., Thisyakorn, U., Thisyakorn, C., 2002. Dengue infection: a global conceren. J. Med. Assoc. Thia., 85:25-33.

Park, J.E., Park, K. 1987.Text book of preventive and social medicine. XI ed. $\mathrm{M} / \mathrm{s}$ Banarsides Bhanot, India. pp:217221.

Parrotta, J.A. 2001. Healing plants of Peninsular India, CABI publishing, 701702.

Powers, A.M., Brault, A.C., Shirako, Y., Strauss, E.G., Kang, W., Stauss, J.H.Weaver S.C. 2001. Evolutionary relationships and systamatics of the alphaviruses. J. Virol., 75: 10118-10131.

Pravin, Y., Saranya, M., Sivakumar, T., Mohanraj, R.S., Dhanakkodi, B. 
2014.Oviposition deterrent activity of acetone leaf extract of Spathodea campanulata P.Beauv. (Bignoniaceae) against chikungunya vector Aedes aegypti (Diptera: Culicidae). Am. J. Pharm. Health Res., 2: 1-16.

Pravin, Y., Saranya, M., Sivakumar, T., Mahendran, S., Mohanraj, R.S.,Dhanakkod B. 2015. Larvicidal, pupicidal, ovicidal activity and GC-MS analysis of Spathodea campanulata

P.Beauv. (Bignoniaceae) acetone leaf extract against the dengue vector mosquito Aedes aegypti (Diptera: Culicidae). Int.J.Curr.Res.Aca.Rev., 3: 92-111.

Prempree, P.,Sukhapanth, N. 1990. Phytochemical toxicity of the crude extract from Derris elliptica

Bentham on mosquito larvae. J. Sci. Soc.Thailand., 16 : 133 -139.

Promsiri, S., Naksathit, A., Kruatrachue, M., Thavara, U. 2006. Evaluations of larvicidal activity of medicinal plant extracts to Aedes aegypti (Diptera : Culicidae) and other effects on a nontarget fish. Insect Science., 13: 179 - 188.

Radhika, W., Sarita, K. 2015. Investigations on the oviposition deterrence and ovicidal potential of the leaf extracts of Argemone mexicana aganist an Indian strain of dengue vector, Aedes aegypti (Diptera: Culicidae). Appl. Res. J., 4: 208-215.

Rajkumar, S., Jebanesan, A. 2005 a. Oviposition deterrent and skin repellent activities of Solanum trilobatum leaf extract against the malarial vector Anopheles stephensi. J. Insect. Sci., 5: 3.

Rajkumar, S., Jebanesan, A.2004. Ovicidal activity of Solanum trilobatum L. (Solanaceae) leaf extract against Culex quinquefasciatus Say and Culex triaeniorhynchus Giles (Diptera : Culicidae). Int. J. Trop. Ins. Sci.,24: 340342.

Rajkumar, S., Jebanesan, A., Nagarajan, R. 2011. Effect of leaf essential oil of Coccinia indica on egg hatchability and different larval instars of malarial mosquito Anopheles stephensi. Asian
Pac. J. Trop. Med., 4 : 948-951.

Rajeswary, M., Govindarajan, M. 2016. Mosquito repellent potential of Pithecellobium dulce leaf and seed against malaria vector Anopheles stephensi (Diptera: Culicidae). J. Cos. Life Med., 4:236-239

Ramanibai, R., Mahavarani, A., Boomilingam, M.2011. Larvicidal efficacy of Leucas aspera (Wild) extracts against the mosquito larvae of Culex quinquefasciatus. J. Pharma. Res., 4: $4424-4425$.

Rao, M.S., Murty, U.S.N., Gangadau, B., Raju, B.C., Ramesh, C., Kumar, S.B., Rao V.J. 2008. Larvicidal efficacy of neonicotinoid classes of compounds on Culex quinquefasciatus. J.Entomol., 5 : 45-50.

Reuda, L.M.2008. Global diversity of mosquitoes (Insecta: Diptera: Culicidae) in freshwater. Develop. Hydrobiol., 595: 477-487

Roni, M., Murugan, K., Christina Mary., Sivapriyajothi, S., Sugana, S., Dinesh, N.A.,Vivek, S. 2013. Ovicidal and adulticidal activity of Nerium oleander extract against Anopheles stephensi Liston (Diptera:Culicidae). Int.J. Innovat. Res., 1:12-18.

Rutledge, C.R., Clarke, F., Curtis, A., Sackett, S. 2003. Larval mosquito control. Tech. Bull. Florida Mosq. Control Assoc.,4 :1619.

Sahgal, A., Pillai, M.K.K., 1993.Ovicidal activity of permethrin and detamethrin on mosquitoes.Entomon, 17:149-154.

Samuel, T., Ravindran, J., Eapen, A., William, J. 2015. Ovicidal activity of Ageratum houstonianum Mill. (Asteraceae) leaf extracts against Anopheles stephensi, Aedes aegypti and Culex quinquefasciatus (Diptera: Culicidae).Asian Pac. J. Trop. Dis., 5: 199-203.

Saranya, M., Mohanraj, R.S., Dhanakkodi, B. 2013a. Ovicidal and oviposition deterrence activity of aqueous leaf extract of Spathodea campanulata P. Beauv.(Bignoniaceae) against Aedes aegypti (Diptera:Culicidae). Int. J.Rec. 
Sci. Res.,4: 28-34.

Saranya, M., Mohanraj, R.S., Dhanakkodi, B. 2013b. Larvicidal, pupicidal activites and morphological deformities of Spathodea campanulata aqueous leaf extract against the dengue vector Aedes aegypti. Euro. J. Exp. Bio., 3:203-213.

Saranya, M., Mohanraj, R.S., Dhanakkodi, B. 2013c. Adult emergence and prolong larval duration effects of Spathodea campanulata aqueous leaf extract against the dengue vector Aedes aegypti. Advance Appl. Sci. Res.,4: 372 - 380

Sarita, K., Naim, W., Monika, M., Radhika, W. 2012. Evaluation of 15 local plants species as larvicidal agents against an Indian strain of dengue fever mosquito, Aedes aegypti L. (Diptera : Culicidae). Front. Physiolo., $3: 1-6$.

Saroj, B., Raksha, R.R., Satvaker, R.R., Ramaiya, M.2016.Larvicidal and growth retarding activity of alkalodidal extract of two plants towards Aedes aegypti (Diptera :Culicidae).world J. Phar. Res., 1:998-1004.

Satya, P., Kunapali, A., Vaidyanathan, C.S. 1984. Indolic compounds in the leaves of Tecoma stans. Phyto. Che.,23: 18261827.

Scott, T.W., Chow, E., Strickman, A., Kittqyapong, P., Writz, R.A., Lorenz, L.H., Edman J.D. 1993. Blood feeding patterns of Aedes aegypti (Diptera: Culicidae) collected in rural Thai village. J. Med. Ent., 30: 922 - 927.

Shapiro, K., Gong, W.C. 2002. Natural products used for diabetes. J. Amer. Pharm. Asso., $\quad$ 42: 217-226.

Sharma, R.N., Gupta, A.S., Patwardhan, S.A., Hebbalkar, D.S., Tare V., Bhonde S.B.1992. Bioactivity of Lamiaceae plants against insects. Indian. J. Exp. Biol.,30: 244- 246.

Singh, S.P., Raghavendra, K., Singh, P.K., Subbarao, S.K. 2001. Studies on larvicidal properties of aqueous extract of Solanum nigrum Linn. (Family : Solanaceae).Current Science,81 : 15291530.

Sukumar, K., Perich, M.J., Boobar, L.R.1991. Botanical derivatives in mosquito control: a review. J. Am. Mosq. Control. Assoc., 7: 210-237.

Swathi, S., Muruganathan, G., Ghosh, S.K.2010. Oviposition deterrentactivity from the ethanolic extract of Pongamia pinnata, Coleus forskohlii and Datura stramonium leaves against Aedes aegypti and Culex quinquefasciatus. Pharmacogn. Mag., 6 : $320-324$.

Swathi,S.,Muruganathan, G.,Ghosh, S.K.,Pradeep, A.S.2012. Larvicidal and repellent activities of ethanolic extract of Datura stramonium leaves against mosquitoes. Int. J. Phar. Phyto. Res., 4:25-27.

Thangarasu M., Kaliyamoorthy, K., Kuppusamy, E. 2014. Pesticidal and Mosquitocidal activities of Clausena excavate Burm.F. (Rutaceae) against Spodoptera litura (Fab.) (Noctuidae: Lepidoptera) and Aedes aegypti L., Anopheles stephensi Liston, and Culex quinquefasciatus Say. (Diptera:Culicidae). Adv. In Zool., 1-7.

The Dinakaran, 2015. The Dinakaran Daily. $17^{\text {th }}$ Febraury.

The Dinamalar, 2014a. The Dinamalar Daily. $16^{\text {th }}$ November.

The Dinamalar, 2014b. The Dinamalar Daily. $10^{\text {th }}$ December.

The Dinamani, 2013.The Dinamani daily. $17^{\text {th }}$ August.

The Hindu, 2001.The Hindu daily. $18^{\text {th }}$ October.

The Hindu, 2006.The Hindu daily. $18^{\text {th }}$ October

The Hindu, 2012.The Hindu daily. $15^{\text {th }}$ July.

Vasuki, V.1991. Ovipositional response of vector mosquitoes to the IGR - treated water. Entomon., 16:175 -178.

Vijaya kumar, S., Arunkumar, R., Mani, P., John Bastin, M.M.,Ravikumar,G.2011a. Mosquito larvicidal, oviposition deterrent and repellent properties of Vitex negundo L.extracts against Aedes aegypti, Anopheles stephensi and Culex quinquefasciatus. J.Pharma. Res., 4: 2060-2063.

Vijaya kumar, S., Mani, P., John Bastin, T.M.M., $\quad$ Arunkumar, R., 
Ravikumar,G.2011b. Larvicidal, ovipositional deterrent and repellent activity of Annona squamosa extracts against hazardous mosquito vectors. Int. J. Pharma. Tech., 3: 3143 -3155.

Villani, F., White, G.P., Curtis, C.F., Miles, S.J.1983. Inheritance and activity of some estrases associated with organophosphate resistance in mosquitoes to the comple of Culex pipiens L. (Diptera: Culicidae). Bull.Ent. Res.,73: 153 - 170.

Waliwitiya, R., Kenny, C.J., Lowenberger, CA. 2009. Larvicidal and ovipositionaltering activity of monoterpenoids, transanethole and rosemary oil to the yellow fever mosquito Aedes aegypti (Diptera: Culicidae) Pest. Manag.Sci.,65:241-248.

Wannee, J.2016. Larvicidal and histopathological effects of Andrographis paniculata leaf extract against Culex quinquefaciatus larva.Walailak J. Sci.Tech., 13:133-140.

Weaver, A., Scott, C., Lecuit, A., Merc, C. 2015. Chikungunya virus and the global spread of a mosquito-borne disease. New Eng. J. Med., 372: 1231- 1239.

Weaver, A., Scott, C., Osorio., Jorge, E., Livengood, Jill, A., Chen, Rubing, Stinchcomb., Dan, T. 2012. Chikungunya virus and prospects for a vaccine. Exp. Rev. Vacc., 11: 1087-1101.

Winkelman, M. 1986. Frequantly used medicinal plants in Baja California Norte. J.Ethnopharm., 18: 109-131.
Xue, R.D., Barnard, D.R., Ali, A. 2003. Laboratotry evaluation of 18 repellent compounds as oviposition deterrents of Aedes albopictus and as larvicides of Aedes aegypti, Anopheles quadrimaculatus and Culex quiquefasciatus. J. Am. Mosq. Control. Assoc., 11: 72-76.

Xue, R.D., Barnard, R, Ali, A.2001. Laboratory and field evaluation of insect repellent as oviposition deterrents against the mosquito Aedes albopictus. Med. Vetri. Entomol., 15: 126-131.

Yadav, R., Tyagi, V., Tikar, S.N., Sharma, A.K., Mendki, M.J., Jain, A.K.2014. Differential larval toxicity and oviposition altering activity of some indigenous plant extracts gainst dengue and chikungunya Vector Aedes albopictus. J. Arthropod- Brone Dis., 8 :174-185.

Yang, P., Yajun, M. A., Shuiqing, Z. 2005. Adulticidal activity of five essential oils against Culex uinquefasciatus.J. Pestic Sci., 30: 89.

Zuharah, W.F., Ling, C.J., Zulkifly, N., Fadzly, N. 2015. Toxicity and sub-lethal effect of endemic plants from family Anacardiaceae on oviposition behaviour of Aedes albopictus. Asian Pac. J. Trop. Biomed.,5: 612-618.

\section{How to cite this article:}

Navaneethan, M., Y. Pravin, M. Saranya, T. Sivakumar, R. S. Mohanraj and Dhanakkodi, B. 2016. Tecoma stans (L.) Juss.ex Kunth (Bignoniaceae) a Prospective Mosquitocide in the Management of Zika Virus Vector Mosquito Aedes aegypti (Diptera:Culicidae). Int.J.Curr.Microbiol.App.Sci.5(4): 869-889. doi: http://dx.doi.org/10.20546/ijcmas.2016.504.099 